\title{
KINETICS AND MECHANISM OF THE IRON ELECTRODE IN SOLUTIONS OF HCl IN DIMETHYLSULPHOXIDE*
}

\author{
D. Posadas, A. J. Arvía and J. J. Podestá \\ Instituto Superior de Investigaciones, División Electroquímica, Facultad de Ciencias \\ Exactas, Universidad Nacional de La Plata, La Plata, Argentina
}

\begin{abstract}
The kinetics of polycrystalline iron electrodes has been investigated under different experimental conditions, employing solutions of hydrogen chloride in dimethylsulphoxide in the presence of $\mathrm{KClO}_{4}$ as supporting electrolyte. Anodic $E / I$ curves exhibit active and passive regions, the former having a Tafel slope of $2 R T / 3 F$. At the lower cathodic polarizations, hydrogen discharge occurs and at higher, the electrodeposition of ferrous ion takes place; both reactions have Tafel slopes of $2 R T / F$. Other kinetic parameters obtained include the reaction orders, dependence of corrosion potential on $\mathrm{HCl}$ concentration, non-steady slopes from decay curves, experimental activation energy, etc.

The interpretation of the reactions is given in terms of a consecutive reaction mechanism involving the participation of solvent ions. The reaction scheme is formally the same as already discussed for the iron electrode in aqueous solutions to explain the $2 R T / 3 F$ anodic Tafel slope.
\end{abstract}

Résumé-On a étudié dans des conditions expérimentales différentes la cinétique des électrodes de fer polycristallin avec des solutions d' $\mathrm{HCl}$ dans DMSO contenant du $\mathrm{KClO}_{4}$ comme électrolyte inerte. Les courbes $E / I$ anođiques présentent deux régions l'une active et l'autre passive. La première a une pente de Tafel de $2 R T / 3 F$. La courbe $E / I$ cathodique, obtenue à de bases polarisations, comprend la décharge d'hydrogène et à des polarisations élevées l'électrodéposition d'ions ferreux. Ces deux réactions sont caractérisćes par des pentes de Tafel de $2 R T / F$.

Parmi les autres paramètres obtenus figurent les ordres des réactions, la dépendance du potentiel de corrosion de la concentration d' $\mathrm{HCl}$, les pentes des courbes $E$ /temp obtenues lors de l'interruption de l'électrolyse, l'énergie d'activation expérimentale, etc.

Les résultats sont interprétés moyennant un mécanisme de réactions successives comprenant la participation des ions produits par le solvant même. Le schéma de réaction est formellement le même que celui qui fut discuté déjà pour expliquer la pente anodique $2 R T / 3 F$ dans le cas des électrodes de fer dans des solutions aqueuses.

Zusammenfassung-Es wurde die Kinetik polykristalliner Eisen-Elektroden unter verschiedenen experimentellen Bedingungen in $\mathrm{HCl}$ Lösungen in DMSO in Gegenwart von $\mathrm{KClO}_{4}$ als InertElektrolyt untersucht. Die anodischen $E / I$-Kurven zeigen eine aktive und eine passive Zone, von denen erstere eine Tafel-Neigung von $2 R T / 3 F$ besitzt. Die kathodischen $E / I$-Kurven zeigen bei niedern Potentialen Wasserstoffentladung, während bei höheren Potentialen Abscheidung von Eisenionen auftritt. Beide Reaktionen sind durch Tafel-Neigungen von $2 R T / F$ charakterisiert.

Ferner wurden andere kinetische Parameter wie Reaktionsordnung, Abhängigkeit des Korrosions-

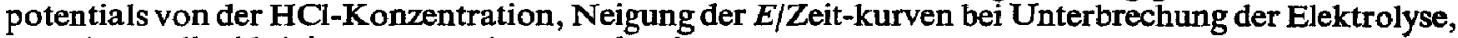
experimentelle Aktivierungsenergie u.s.w. bestimmt.

Die Ergebnisse werden mit einem Mechanismus aufeinander-folgender Reaktionen interpretiert, bei denen eine Teilnahme von Lösungsmittelionen stattfindet. Das Reaktionsschema ist formell das gleiche, wie es bereits für die Eisenelektrode in wässerigen Lösungen diskutiert wurde, um die $2 R T / 3 F$ anodische Tafel-Neigung zu erklären.

\section{INTRODUCTION}

Most of the published results on the kinetics and mechanism of iron electrode reactions, as well as the metallic corrosion processes, refer principally to aqueous solutions. There are only few systematic investigations covering the behaviour of metal electrodes in melts and still fewer in non-aqueous solvents.

At present much attention is being paid to establish the role played by the solvent in electrode reactions and as far as this aim is concerned, we have attempted to study the iron electrode in a non-aqueous ionic solution such as that of hydrogen chloride

- Manuscript received 27 November 1969. 
in dimethylsulphoxide. Many reasons favour the choice of the iron electrode reactions for the purpose; in particular, the iron electrode reactions have been studied in detail employing different aqueous solutions and a good deal of sound information is now available. ${ }^{1-17}$

As far as the solvent is concerned, dimethylsulphoxide is a versatile aprotic solvent in which most of the soluble 1-1 type electrolytes are completely or almost completely dissociated. ${ }^{18-20}$ Because of the basic properties of the solvent hydrogen chloride dissolves to a large extent in it. Ferrous and ferric ions can exist as complexes; ${ }^{21}$ the former, as perchlorate having the formula $\mathrm{Fe}(\mathrm{DMSO})_{6}\left(\mathrm{ClO}_{4}\right)_{2}$, is rather unstable as compared to the latter, whose formula is $\mathrm{Fe}(\mathrm{DMSO})_{6}\left(\mathrm{ClO}_{4}\right)_{3}$. Both complexes have been isolated as solids and studied by ir spectroscopy. ${ }^{22-24}$ The complexes involving the corresponding halides probably involve co-ordinate bonds between the anion and the metallic atom.

In the present paper the range of potential covering the anodic dissolution of the metal as well as the region of cathodic electrodeposition has been investigated. In between, at low cathodic polarizations the electrodeposition of hydrogen takes place, as already discussed. ${ }^{25}$ If the kinetic parameters of the iron electrode and those of the hydrogen evolution reaction on iron in $\mathrm{HCl}-\mathrm{DMSO}$ solutions are known, the probable mechanisms of iron corrosion in these ionic solutions can be discussed.

\section{EXPERIMENTAL TECHNIQUE}

A three-section Pyrex glass electrolysis cell was employed. Each section could be isolated by means of Pyrex taps, lubricated with the non-aqueous solution. The cell was air-tight and a controlled atmosphere could be kept independently in each section. The working electrode was an iron wire held vertically in a Teflon holder. An aqueous saturated calomel electrode was used as a reference. It was placed in a double sheath to avoid as much as possible any water diffusion into the non-aqueous solution. The counter-electrode was a platinum sheet $c a 10 \mathrm{~cm}^{2}$.

Johnson, Matthey polycrystalline iron wires of $0.5-\mathrm{mm}$ diameter were used as working electrodes. The impurity content was: $\mathrm{Ni}, 3 \mathrm{ppm} ; \mathrm{Mn}$ and $\mathrm{Mg}, 2 ; \mathrm{Cu}$ and $\mathrm{Ag},<1$.

To obtain reproducible results the iron wires were electropolished before use in a solution of perchloric acid in butylcellosolve, as indicated in the literature; DMSO (Fluka, Hopkins and Williams) was used as solvent. It was first treated with alumina and then distilled three times under reduced pressure according to the method given elsewhere. ${ }^{20}$ The purity of the solvent as far as water and traces of any other organic substances are concerned was tested with calcium hydride and gas chromatography, respectively. ${ }^{27}$ The water content was $\ll 1 \%$ and no traces of organic impurities were detected.

Hydrogen chloride was obtained by dehydrating a concentrated hydrochloric acid solution with concentrated sulphuric acid. The purified gas was dissolved in DMSO, the latter being kept at the lowest possible temperature as liquid. ${ }^{28}{ }^{29}$ Solutions containing ferrous ion were prepared by two different methods, either electrochemically, by anodic dissolution of known amounts of pure iron, or by first preparing the $\mathrm{Fe}(\mathrm{DMSO})_{6}\left(\mathrm{ClO}_{4}\right)_{2}$ complex ${ }^{21}$ and dissolving it into the $\mathrm{HCI}-\mathrm{DMSO}$ solution. The solutions were kept in contact with an inert atmosphere during the preparation as well as when passing them from the main container to the electrolysis cell. Hydrogen, 
nitrogen and oxygen were employed in different runs to saturate the working electrode compartment. These gases were purified by using well known techniques.

Coulometric as well as galvanostatic and potentiostatic techniques under steady and non-steady conditions were employed covering for the anodic process a $\mathbf{H C l}$ concentration range from 0.002 to $0.125 \mathrm{M}$ and up to $0.005 \mathrm{M}$ ferrous ion concentration. For the cathodic process $0.005 \mathrm{M} \mathrm{HCl}$ solutions covering a ferrous ion concentration from 0.1 to $1 \mathrm{~N}$ were employed. All solutions contained $\mathrm{KClO}_{4} 1 \mathrm{M}$ as supporting electrolyte. The experiments were carried out at 25,35 and $45^{\circ} \mathrm{C}$.

\section{Coulometric analyses}

\section{RESULTS}

Coulometric analyses were made to establish the anodic efficiency for iron dissolution. $\mathrm{HCl}$ solutions were electrolysed at different currents and the amount of iron dissolved was evaluated spectrophotometrically. ${ }^{30}$ A silver coulometer was employed to determine the charge passed. In the cd range from $1 \times 10^{-3}$ to $1.5 \times 10^{-3} \mathrm{~A} / \mathrm{cm}^{2}$, the reaction occurs with an efficiency close to $100 \%$ as expressed by

$$
\mathrm{Fe}=\mathrm{Fe}^{2+}+2 \mathrm{e} \text {. }
$$

\section{Corrosion potential}

Iron electrodes immersed in hydrogen-saturated HCl-DMSO solutions containing the supporting electrolyte exhibit a corrosion potential, $E_{\text {corr }}$, which is logarithmically related to the hydrogen chloride concentration, $c_{\mathrm{H}}$, according to

$$
E_{\text {corr }}=E_{\mathrm{k}}+k \log c_{\mathrm{H}} \text {, }
$$

as shown in Fig. 1. $E_{\mathrm{k}}$ and $k$ are constants. The dependence of the corrosion potential on the $\mathrm{HCl}$ concentration is given by

$$
\left(\frac{\partial E_{\text {corr }}}{\partial \log c_{\mathrm{H}}}\right)=(0.054 \pm 0.010) \mathrm{V} \text {. }
$$

In the following paragraphs the corrosion potential is used as the reference potential to define the overvoltage of the working electrode, $\eta$.

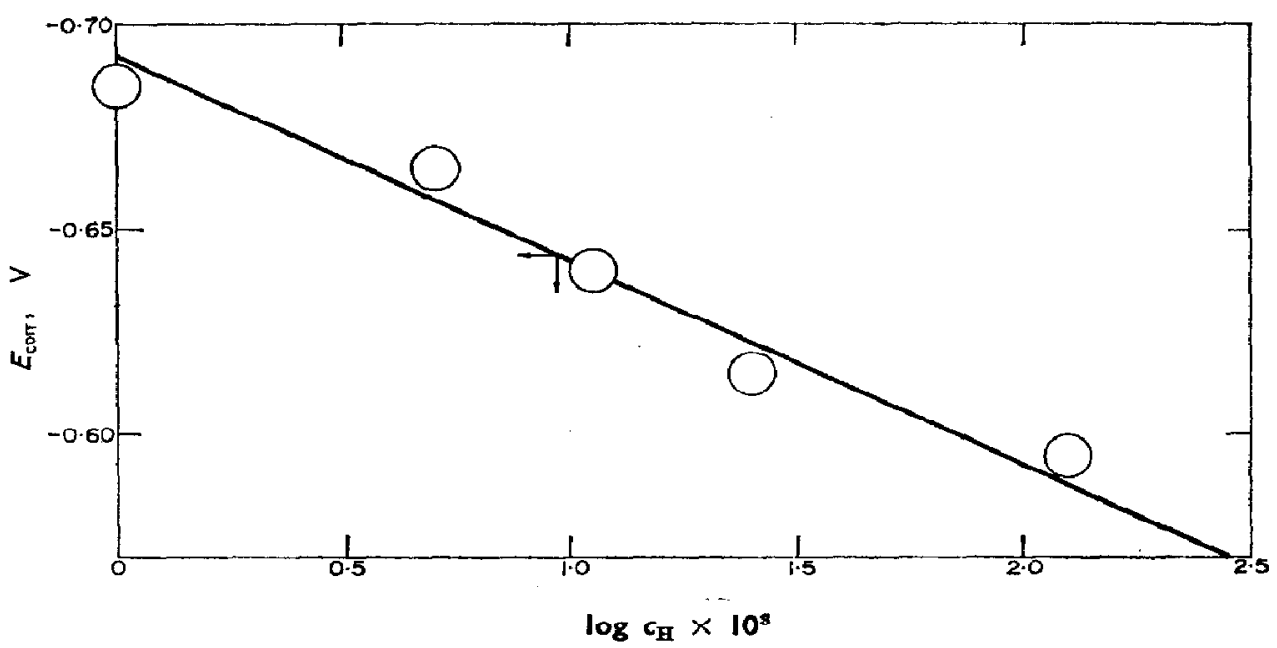

Fio. 1. Dependence of corrosion potential on concentration of $\mathrm{HCl}$. $25^{\circ} \mathrm{C} ; 1 \mathrm{M} \mathrm{KClO}, ; p_{\mathrm{H}_{\mathrm{a}}}=1 \mathrm{~atm}$. 


\section{Anodic current/potential curves}

To establish any effect of stirring on the electrode process, current/potential curves were obtained under three different conditions, namely (i) with the electrolyte solutions at rest; (ii) by bubbling hydrogen gas at different flow rates, and (iii) by means of an iron rotating disk electrode in order to obtain a definite hydrodynamic. There was no difference between (ii) and (iii). There was a definite difference when either (ii) or (iii) was compared with (i), particularly when the potentials were so positive that passivity interfered in the process.

Anodic current/voltage curves in the active region are not affected by ferrous ion concentration or by the addition of supporting electrolyte or other gases, such as nitrogen instead of hydrogen. There is, however, a net effect of the $\mathrm{HCl}$ concentration and a small effect of stirring, particularly at high positive potentials.

Experimental potential/log (apparent cd) plots deviate from a Tafel line, as depicted in Fig. 2 for hydrogen-saturated solutions; the slope of these curves increases continuously as the anodic polarization increases. This effect prevents the straightforward evaluation of any kinetic parameter for the anodic reaction. The behaviour is often found when the rest potential of the working electrode actually is a corrosion potential, when two electrode processes are simultaneously occurring on the metal surface and no net external current flows. In the absence of oxygen, the main processes are the iron-dissolution and hydrogen-evolution reactions. Hence, the experimental polarization curves involve the total current, $I$, and in order to evaluate the kinetic parameters of the anodic process the anodic partial current must be used. If the partial current related to the hydrogen evolution is $I_{o}$, the anodic partial current, $I_{\mathrm{a}}$, is given by

$$
I_{\mathrm{a}}=I-I_{\mathrm{c}} .
$$

$I_{\mathrm{c}}$ can be immediately obtained, since the kinetics of the cathodic evolution of

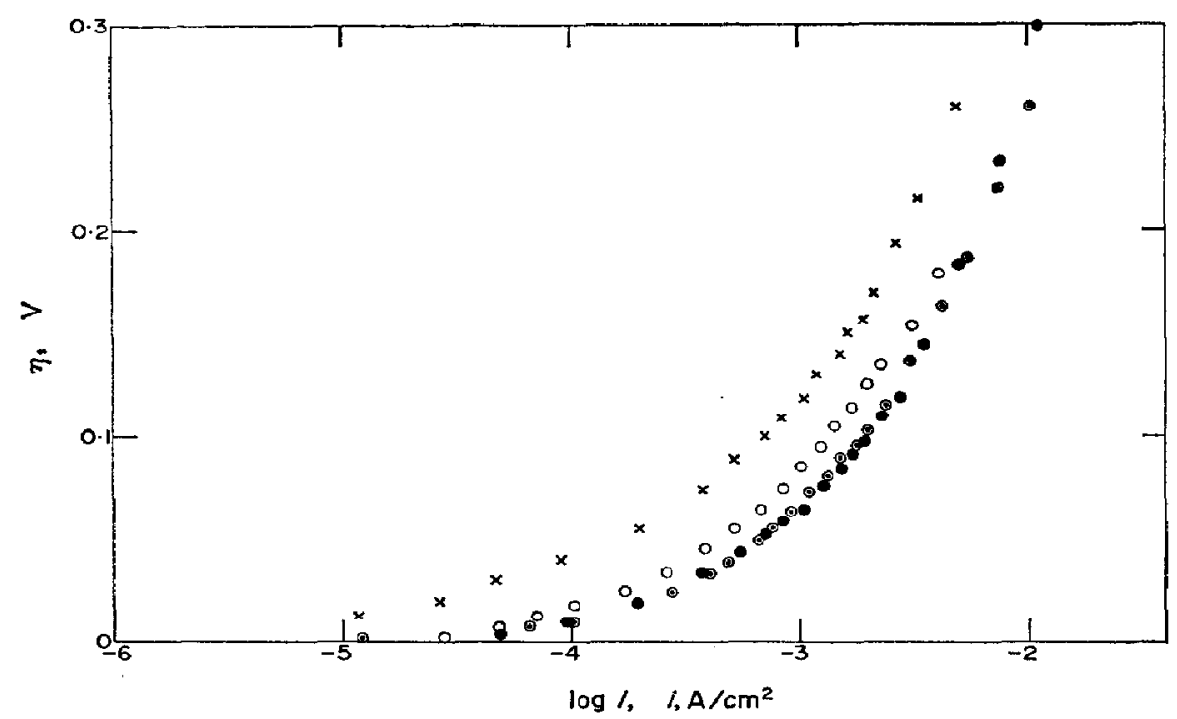

FTG. 2. Anodic Tafel plots.

$25^{\circ} \mathrm{C} ; 1 \mathrm{M} \mathrm{KClO}{ }_{4} ; p_{\mathrm{E}_{3}}, 1 \mathrm{~atm}$.

$\times, c_{\mathrm{H}}=0.002 \mathrm{M} ; O, c_{\mathrm{H}}=0.02 \mathrm{M} ; \bullet, c_{\mathrm{H}}=0.125 \mathrm{M} ; 0, c_{\mathrm{H}}=0.125 \mathrm{M} ; c_{\mathrm{F}_{0}}=0.005 \mathrm{M}$. 
hydrogen on iron, employing the same solutions, is known. ${ }^{25}$ Figure 3 shows a semilogarithmic plot after the above correction was made. To obtain this result it was reasonably assumed that in the active region the partial cathodic current for ferrous ion is negligible and that the anodic current for hydrogen dissolution is also negligible. In a range comprising 1.5 logarithmic decades of current the anodic dissolution of iron fits a Tafel line with a slope, $b_{\mathrm{T}, \mathrm{a}}$, very close to $2 \cdot 3(2 R T / 3 F) \mathrm{V}$ as reported in Table 1. At higher anodic polarizations, in spite of the above mentioned correction, there is an increasing departure from the Tafel line, due to the onset of the passivity.

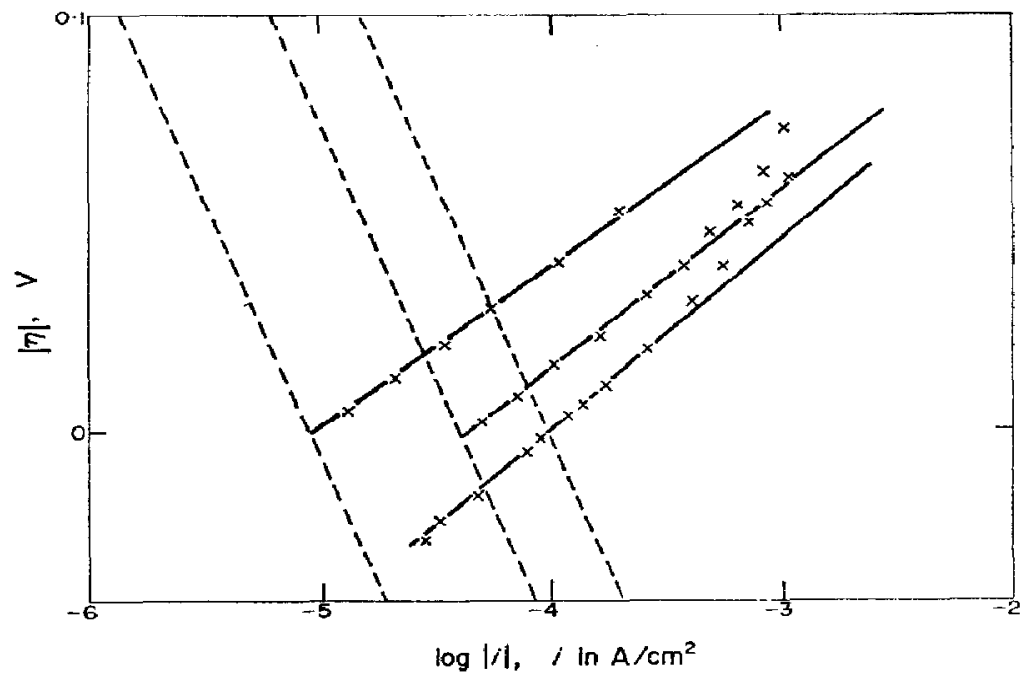

Fig. 3. Corrected anodic Tafel plots.

$25^{\circ} \mathrm{C} ; 1 \mathrm{M} \mathrm{KClO}{ }_{4} ; p_{\mathrm{H}_{2}}, 1 \mathrm{~atm}$. $c_{\mathrm{B}}$ as in Fig. 2. Full lines correspond to an anodic Tafel slope, $b_{\text {T.a }}=2 \cdot 3(2 R T / 3 F)$. Dotted lines correspond to the extrapolated cathodic Tafel lines for hydrogen evolution, Tafel slope, $b_{\mathrm{T}, \mathrm{H}}=2 \cdot 3(2 R T / F)$.

On increasing the $\mathrm{HCl}$ concentration at a constant anodic overvoltage there is a net increase of current, Fig. 2. A $\log / \log$ plot of current density $v s \mathrm{HCl}$ concentration at constant overvoltage yields a straight-line relationship, Fig. 4. By extrapolating the anodic Tafel line to the corrosion potential, the apparent corrosion cd, $i_{\text {orr }}$, can be evaluated. From Figs. 2-4, the following relationships are derived,

$$
\left(\frac{\partial \log i_{\mathrm{a}, \mathrm{Fe}}}{\partial \log c_{\mathrm{H}}}\right)_{\eta}=\left(\frac{\partial \log i_{\text {corr }}}{\partial \log c_{\mathrm{H}}}\right)_{E_{\mathrm{corr}}}=0.5 \pm 0 \cdot 1 \text {. }
$$

Taking into account the dependence of $E_{\mathrm{corr}}$ on $c_{\mathrm{H}}$, the Tafel line for hydrogen evolution and the Tafel line for the anodic dissolution of active iron, the semilogarithmic current/voltage curves, in the vicinity of the corrosion potential, take the general picture shown in Fig. 5. From this is deduced

$$
\left(\frac{\partial \log i_{\mathrm{B}, \mathrm{Fe}}}{\partial \log c_{\mathrm{H}}}\right)_{\mathrm{V}}=-0 \cdot 8 \pm 0 \cdot 1 \text {. }
$$

Oxygen gas affects the corrosion process particularly by shifting the corrosion potential towards more positive values. The rest potential at $25^{\circ} \mathrm{C}$ in this case lies at about $-0.39 \mathrm{~V}(\mathrm{sce})$. The current/voltage curve, however, in general maintains $\mathrm{t} 1$ : shape already described in the presence of hydrogen gas. 
D. Posadas, A. J. Arvita and J. J. Podestá

Table 1. Parameters deduced from anodic $\boldsymbol{T} / I$ CURVES: $25^{\circ} \mathrm{C}$.

\begin{tabular}{ccc}
\hline $\begin{array}{c}c_{\mathbf{H}} \\
\mathbf{M}\end{array}$ & $\begin{array}{c}b_{\mathbf{\mathrm { T } , \mathrm { a }}} \\
\boldsymbol{i}_{\mathbf{c o r r}} \times \mathbf{1 0}^{\mathbf{6}} \\
\mathbf{A} / \mathrm{cm}^{\mathbf{2}}\end{array}$ \\
\hline 0.002 & 0.039 & $9 \cdot 1$ \\
0.025 & 0.040 & 38 \\
0.125 & 0.044 & 100 \\
\hline
\end{tabular}

Table 2. Parameters derived from anodic non-steady MEASUREMENTS. $25^{\circ} \mathrm{C}$

\begin{tabular}{|c|c|c|}
\hline$\eta \times 10^{\mathrm{a}}$ & $b_{\mathrm{d}} \underset{\mathrm{V}}{\times 10^{3}}$ & $C_{\mathrm{E} / \mathrm{cm}^{2}} \times 10^{6}$ \\
\hline$c_{\mathrm{H}}, 0-010 \mathrm{M}$ & $c_{\text {Fee }}, 0.005 \mathrm{M}$ & $1 \mathrm{M} \mathrm{KClO}_{4}$ \\
\hline $\begin{array}{l}386 \\
221 \\
166 \\
103\end{array}$ & $\begin{array}{l}72 \\
55 \\
45 \\
39\end{array}$ & $\begin{array}{l}3 \cdot 7 \\
3 \cdot 3 \\
4 \cdot 7 \\
8 \cdot 0\end{array}$ \\
\hline$c_{\mathrm{H}}, 0.014 \mathrm{M}$ & $c_{\text {He, }} 0.005 \mathrm{M}$ & $1 \mathrm{M} \mathrm{KClO}_{4}$ \\
\hline $\begin{array}{r}258 \\
144 \\
100 \\
73\end{array}$ & $\begin{array}{l}72 \\
46 \\
40 \\
38\end{array}$ & $\begin{array}{r}2 \cdot 6 \\
3 \cdot 9 \\
5 \cdot 3 \\
11 \cdot 5\end{array}$ \\
\hline
\end{tabular}

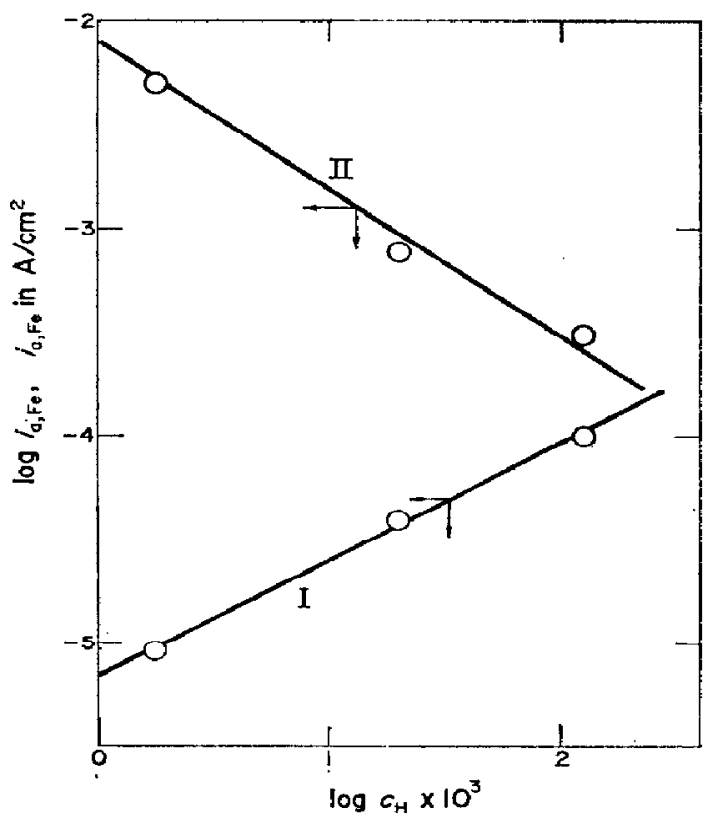

Fir. 4. $\mathrm{Log} / \log$ plot of $i_{\mathrm{A}, \text { pe }}$ on $c_{\mathrm{H}}$.

(I) Dependence of $i_{\mathrm{a}, \mathrm{Fe}}$ on $c_{\mathrm{H}}$ at constant overvoltage.

(II) Dependence of $i_{k, F e}$ on $c_{H}$ at constant anodic potential $V$. $25^{\circ} \mathrm{C} ; P_{\mathrm{B}_{\mathrm{g}}}, 1 \mathrm{~atm}$. 


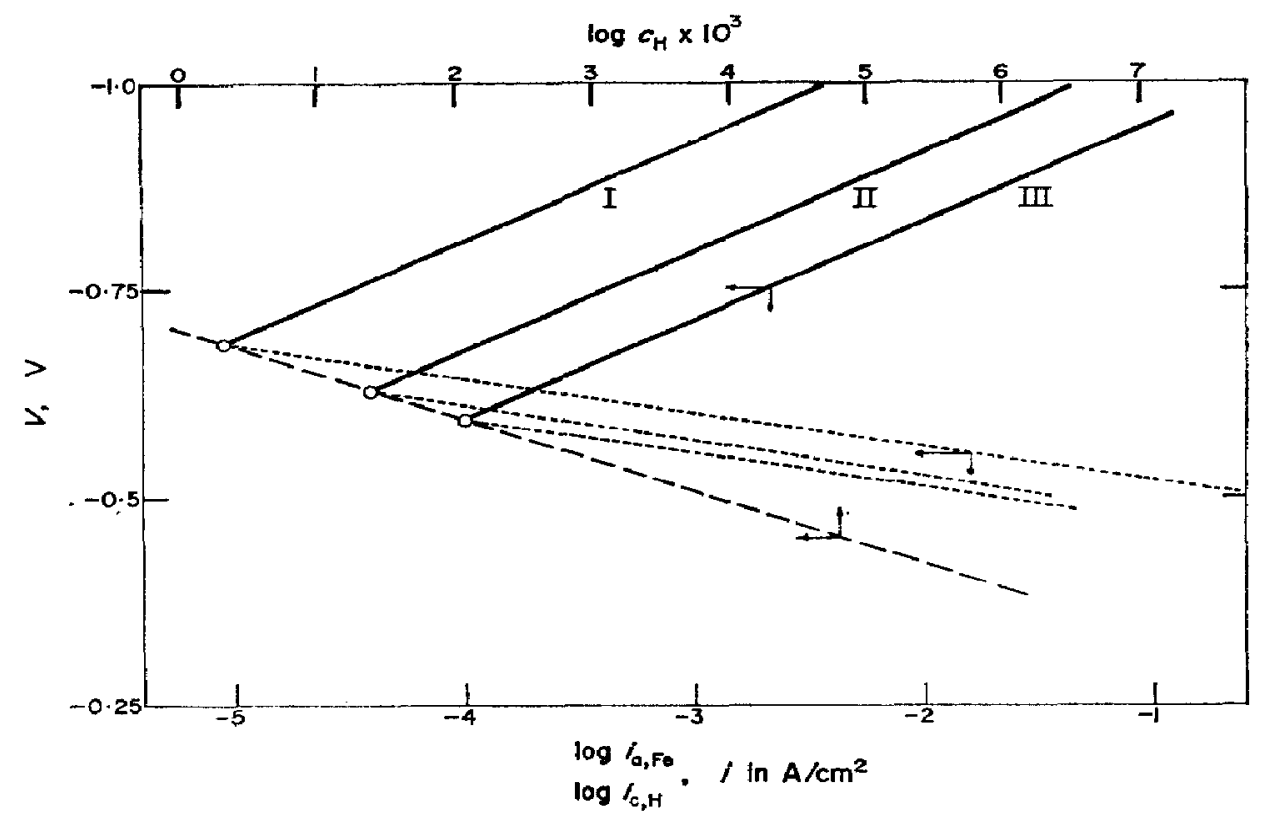

Fio. 5. Tafel lines drawn for the anodic and cathodic processes, slopes $b_{T, \text { a }}$ and $b_{\mathrm{T}, \mathrm{H}}$, respectively.
(I) $c_{\text {H }}, 0.002 \mathrm{M}$;
(II) $c_{\mathrm{H}}, 0.02 \mathrm{M}$
(III) $c_{\mathrm{H}}, 0.125 \mathrm{M} .25^{\circ} \mathrm{C}$.

In conclusion, the rate of the anodic reaction exhibits a minus one order dependence on hydrogen chloride concentration and it is independent of the concentration of ferrous ion. The Tafel slope in the active region is very close to $2 \cdot 3(2 R T / 3 F) \mathrm{V}$ in the whole temperature range investigated.

\section{Temperature effect}

At constant overvoltage a net increase of anodic current is observed as temperature increases. From an Arrhenius plot, at different overvoltages, the experimental activation energy, $\Delta H^{*}$, of the anodic reaction is obtained. The latter depends on overvoltage as shown in Fig. 6 . Its value at the corrosion potential is about $15 \mathrm{kcal} / \mathrm{mol}$. $\Delta H^{*}$ approaches a constant value at high anodic potentials.

\section{Non-steady measurements}

In the active region the anodic overvoltage decays linearly with the logarithm of time, as shown in Fig. 7 for decay runs started at different anodic overvoltages.

To interpret the semilogarithmic plots the same sort of correction already indicated for the steady measurements has to be applied to the anodic potential decay. If the anodic decay at current interruption $(t=0)$ comprises the simultaneous occurrence of two reactions at the electrochemical double layer, and these reactions are the oxidation of iron and the reduction of hydrogen ion, the differential equation that expresses this situation is

$$
C_{\mathrm{e}}(\mathrm{d} V / \mathrm{d} t)+i_{0 . \mathrm{Fe}} \exp \left(\alpha_{\mathrm{a}, \mathrm{Fe}} V F / R T\right)-i_{0 . \mathrm{H}} \exp \left(-\alpha_{\mathrm{e}, \mathrm{H}} V F / R T\right)=0,
$$

where $C_{\mathrm{e}}$ is the differential electrode capacitance, $i_{0, \mathrm{Fe}}$ and $i_{0 . \mathrm{H}}$ are the exchange cds for the iron and hydrogen electrodes respectively and $\alpha_{\mathrm{a}, \mathrm{Fe}}$ and $\alpha_{\mathrm{o}, \mathrm{H}}$ the anodic and cathodic transfer coefficients corresponding to those electrodes. If the third term is 


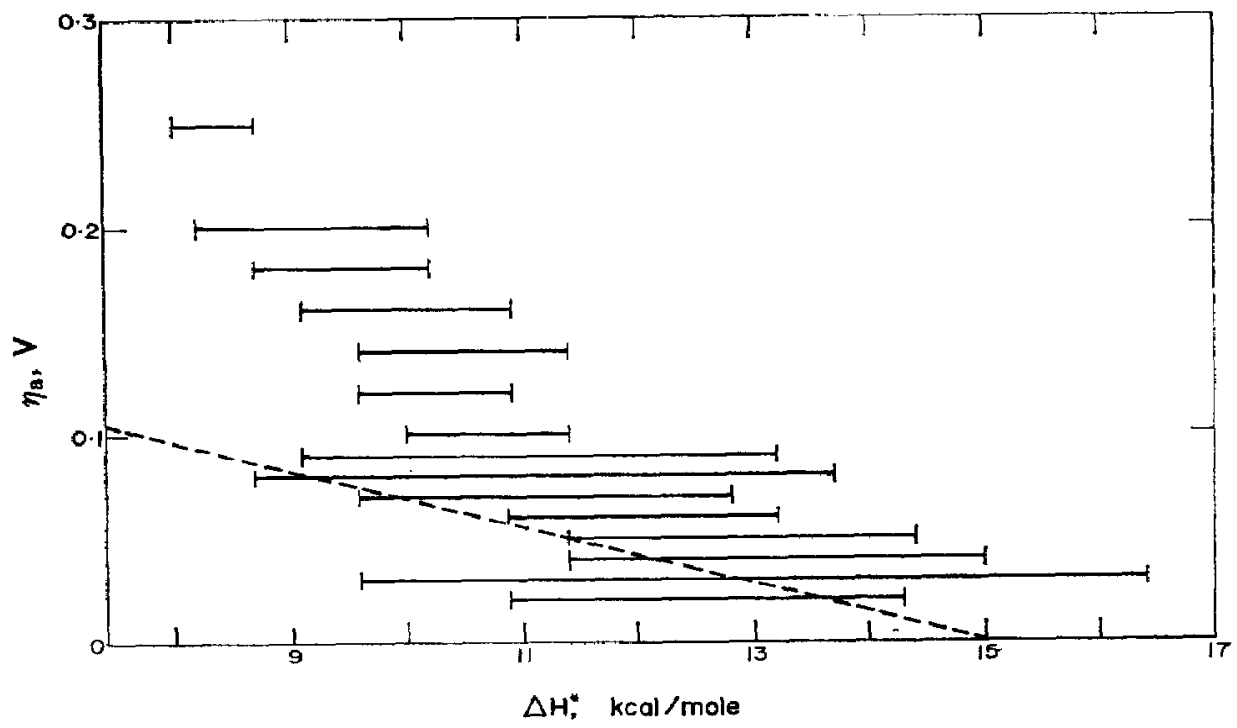

FIG. 6. Dependence of $\Delta H^{*}$ on anodic overvoltage. Dotted line has the slope expected from the rate equation for the anodic dissolution of iron, assuming $\alpha_{\mathrm{a}, \mathrm{Fe}}=\frac{3}{\mathrm{n}}$.

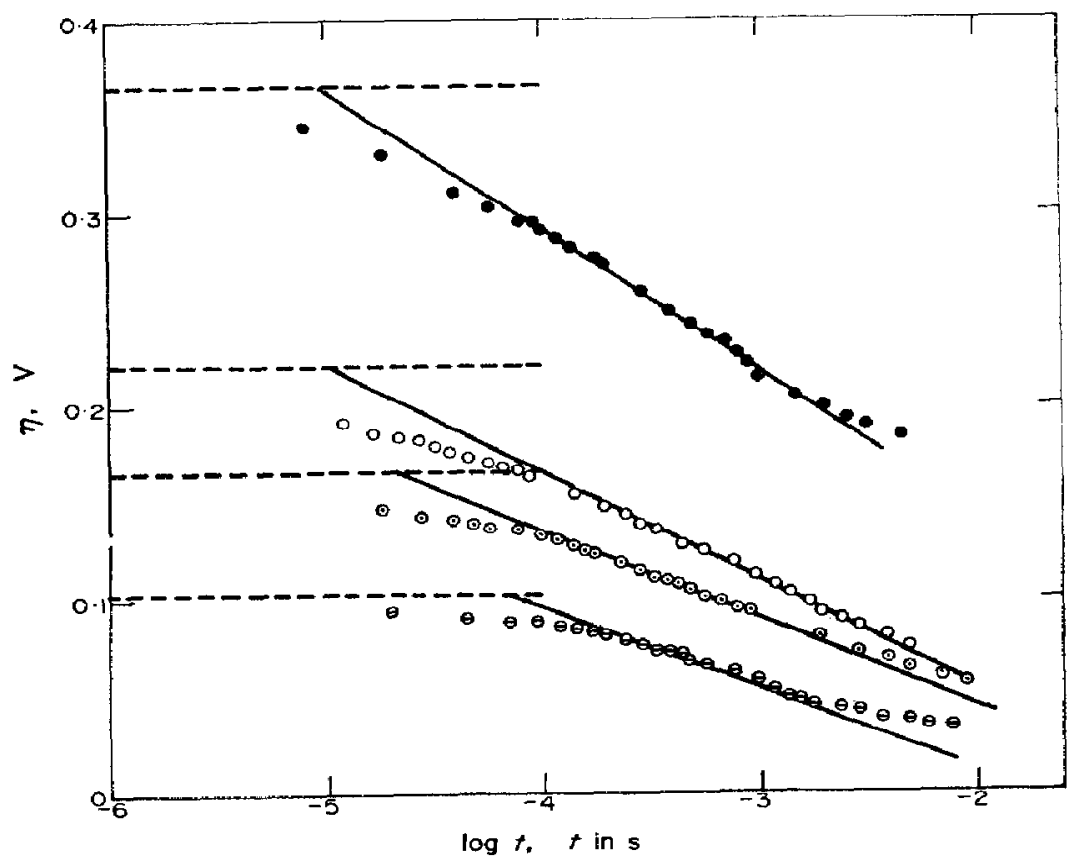

FrG. 7. Semilogarithmic plot of anodic overvoltage decay. $25^{\circ} \mathrm{C} ; c_{\mathrm{H}}, 0.1 \mathrm{M} ; c_{\mathrm{Fe}}, 0.005 \mathrm{M} ; 1 \mathrm{M} \mathrm{KClO}_{4}$.

Dotted lines correspond to the overvoltage at current interruption. 
negligible as compared to the second, which is reasonable at the larger anodic polarizations, then the integration of (7) yields the linear $\eta / \log \left(t+t^{\prime}\right)$ relationship already known. ${ }^{31}$

From the semilogarithmic plots, the decay slope, $b_{\mathrm{d}}$, and the apparent electrode differential capacitance at different overvoltages obtained by extrapolating the straight line at the initial decay potential were evaluated. For decay processes from relatively low initial anodic polarizations, the decay slope is close to $2 \cdot 3(2 R T / 3 F) \mathrm{V}$, but it becomes larger when the decay process starts closer to the region where passivity onset takes place.

The electrode differential capacitances at the corrosion potential calculated from galvanostatic build-up curves lie between 10 to $20 \mu \mathrm{F} / \mathrm{cm}^{2}$. At low overvoltages, the electrode differential capacitance derived from anodic overvoltage decay approaches that obtained at the corrosion potential, but it becomes smaller when the initial decay potential approaches the passive region.

The pseudo-ohmic drop was obtained from the initial instantaneous jump of electrode potential. The $I R$ drop is negligible in the present circumstances, taking into account the range of current covering the active anodic region. No ohmic contribution due to any film formation was detected in this potential region.

\section{Cathodic current/potential curves}

The discharge of hydrogen ion occurs at the lower cathodic polarizations, as already reported and discussed in a previous publication. ${ }^{25}$ After the hydrogen limiting current is established, at higher cathodic polarizations the electrodeposition of ferrous ion as iron takes place. The cathodic efficiency for iron electrodeposition depends both on the concentration of $\mathrm{HCl}$ and the electrode potential. As the former decreases the cathodic efficiency increases, and after the hydrogen-evolution limitingcurrent region is exceeded, only iron electrodeposition occurs, at least in the cathodic region here covered.

Figure 8 shows a semilogarithmic plot of a cathodic current/potential curve. After correcting for the former reaction, the iron electrodeposition gives a Tafel line whose slope, at $40^{\circ} \mathrm{C}$, is nearly $2-3(2 R T / F) \mathrm{V}$. At a constant cathodic potential, the cd increases with the ferrous ion concentration. As iron electrodeposition occurs after hydrogen ion is depleted at the reaction interface, its influence could not be determined in the present circumstances. Neither hydrogen gas nor solution flow rate have any influence on the cathodic electrodeposition of iron. The latter affects only the region corresponding to the hydrogen-evolution reaction.

Once iron electrodeposition occurred, the rest potential at current interruption was $0.4 \mathrm{~V}$ more negative than the corrosion potential, this potential being probably very close to the $\mathrm{Fe}^{2+} / \mathrm{Fe}$ electrode potential. The cathodic and anodic Tafel lines for the iron electrode reactions intersect at the reversible potential of the iron electrode, and this depends on ferrous ion concentration. Unfortunately this could not be evaluated with accuracy. The intersection point also defines the value of the apparent exchange cd of the iron electrode, $i_{0, \mathrm{Fe}}$, in $\mathrm{HCl}-\mathrm{DMSO}$ solutions. In the range of temperature investigated, it is about $10^{-8} \mathrm{~A} / \mathrm{cm}^{2}$.

To conclude, the electrodeposition of iron gives a Tafel slope of $2 R T / F$ and the position of the line depends on ferrous ion concentration. 


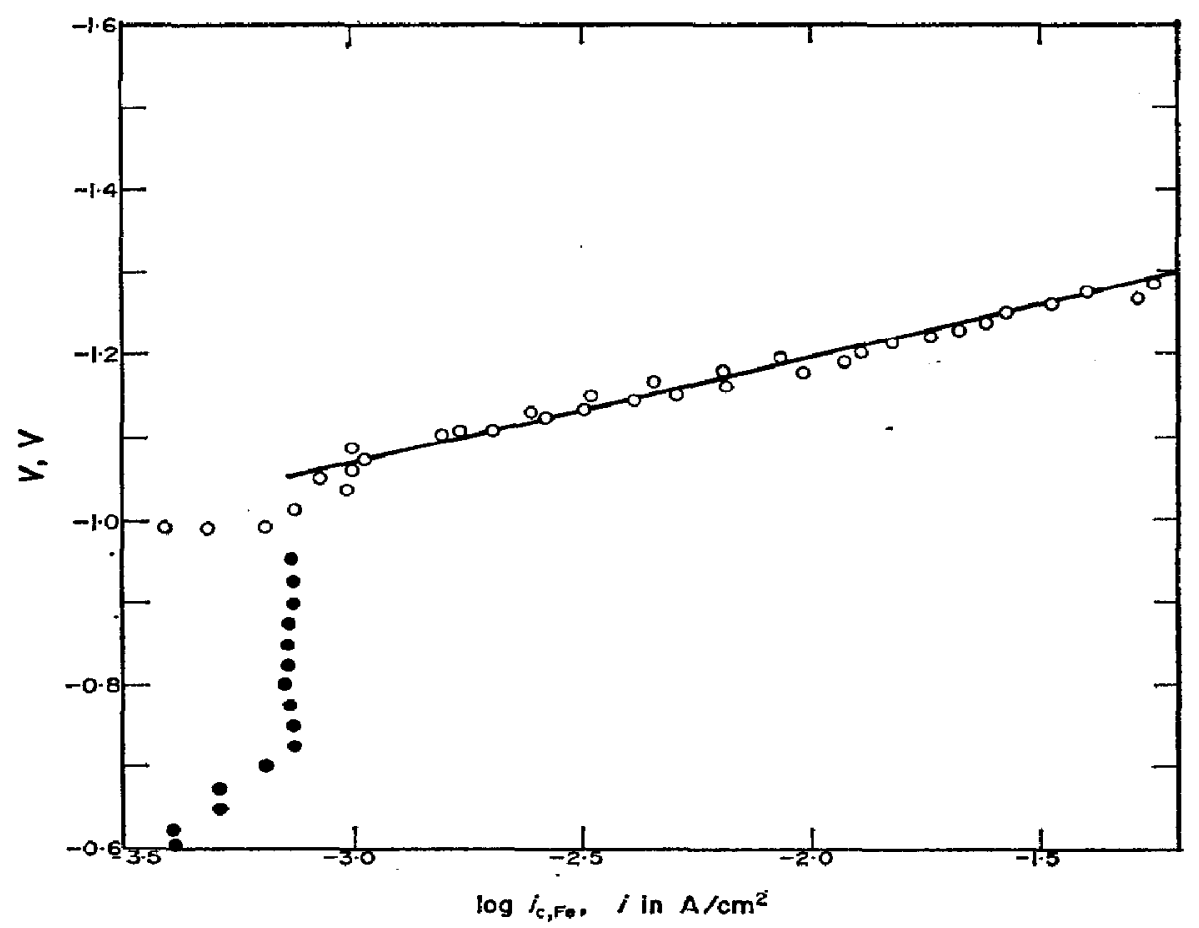

Fio. 8. Cathodic Tafel plots. $40^{\circ} \mathrm{C}, c_{\mathrm{H}}, 0.005 \mathrm{M}$; $c_{\mathrm{Fe}}, 0.5 \mathrm{M} . p_{\mathrm{H}_{2}}, 1 \mathrm{~atm}$. The full line corresponds to the cathodic Tafel line or iron electrodeposition, $b_{\mathbf{T}, \mathrm{e}}$, equal to $2 \cdot 3(2 R T / F)$.

\section{General considerations}

\section{DISCUSSION}

The kinetics of the iron corrosion reaction in $\mathrm{HCl}$-DMSO solutions indicate a clear participation of the solvated proton. Therefore, the rate equations of each reaction participating in the corrosion process should explicitly contain the concentration of the solvated proton. Thus, the $\mathrm{cd} /$ potential relationship for the anodic dissolution of iron, in general, can be expressed as

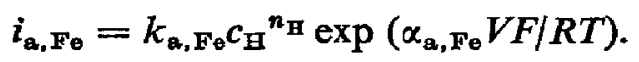

For the cathodic electrodeposition of hydrogen it is

$$
i_{\mathrm{c}, \mathrm{H}}=k_{\mathrm{c}, \mathrm{H}} c_{\mathrm{H}}^{m_{\mathrm{H}}} \exp \left(-\alpha_{\mathrm{e}, \mathrm{H}} V F / R T\right),
$$

and analogously for the cathodic deposition of iron, it is

$$
i_{\mathrm{c}, \mathrm{Fe}}=k_{\mathrm{c}, \mathrm{Fe}} c_{\mathrm{Fe}}^{n_{\mathrm{Pe}}} C_{\mathrm{H}}{ }^{n_{\mathrm{H}}} \exp \left(-\alpha_{\mathrm{c}, \mathrm{Fe}} V F / R T\right) \text {. }
$$

Equations (8)-(10) contain the formal rate constants, $k_{i}$, the concentration of the corresponding species, $c_{i}$, the experimental transfer coefficient, $\alpha_{i}$, the electrode potential, $V$, and the corresponding reaction orders, $n$ and $m$.

When $i_{\mathrm{a}, \mathrm{Fe}}=i_{\mathrm{c}, \mathrm{Fe}}, V$ becomes the reversible potential of the iron electrode, and equating (8) and (10) we get

$$
\alpha_{\mathrm{c}, \mathrm{Fe}}+\alpha_{\mathrm{a}, \mathrm{Fe}}=2 n_{\mathrm{Fe}} \text {. }
$$

The general expression for the electrode potential is

$$
V=\phi^{\mathrm{m}}-\psi_{1},
$$


where $\phi^{\mathbf{m}}$ is a definite Galvani potential, and $\psi_{1}$ the potential of the outer plane of the Helmholtz double layer. The overvoltage $\eta$ is defined taking the Galvani corrosion potential, $\phi_{\text {corr }}^{\mathrm{m}}$, as reference potential, as

$$
\eta=\phi^{\mathbf{m}}-\phi_{\text {oorr }}^{\mathbf{m}} \text {. }
$$

Under a steady state corrosion at the corrosion potential, $E_{\text {corr }}, i_{\mathrm{a} . \mathrm{Fe}}=i_{\mathrm{c}, \mathrm{B}}=i_{\mathrm{corr}}$ and equating (8) and (9) we have

and

$$
E_{\mathrm{corr}}=\frac{m_{\mathrm{H}}-n_{\mathrm{H}}}{\alpha_{\mathrm{g}, \mathrm{Fe}}+\alpha_{\mathrm{o}, \mathrm{Fe}}} \frac{R T}{F} \ln c_{\mathrm{H}}
$$

$$
\left(\frac{\partial \ln i_{\text {corr }}}{\partial \ln c_{\mathrm{H}}}\right)_{E_{\mathrm{corr}}}=n_{\mathrm{H}}+\frac{\alpha_{\mathrm{Q}, \mathrm{Fe}}}{\alpha_{\mathrm{B}, \mathrm{Fe}}+\alpha_{\mathrm{c}, \mathrm{Fe}}}\left(m_{\mathrm{H}}-n_{\mathrm{H}}\right) \text {. }
$$

Equations (8)-(15) are completely general expressions which can be applied to any corrosion process involving the participation of hydrogen ions or any species containing hydrogen ions. In the absence of experimental results that would allow an unambiguous mechanistic interpretation, those equations can be used to derive probable reaction paths, assuming in the anodic dissolution reaction an inverse first-order reaction with respect to hydrogen-ion concentration $\left(n_{\mathrm{H}}=-1\right)$, and in the electrodeposition of iron, first order with respect to ferrous ion $\left(n_{\mathrm{Fe}}=1\right)$. The experimental results indicate that these assumptions are reasonable. Therefore, on the basis of the corrosion potential and corrosion current dependences on hydrogen-ion concentration and a set of values for $n_{\mathrm{H}}$ and $n_{\mathrm{Fe}}$, the probable reaction paths are limited to a few possibilities, already analysed in detail for the iron electrode in aqueous acid solutions. ${ }^{6}$ As the rate expressions derived for $\mathrm{HCl}-\mathrm{DMSO}$ solutions are formally the same as those obtained for the aqueous acid systems the previous mechanistic discussion can be extended to the non-aqueous solution.

Before discussing the probable reaction scheme for the iron electrode in the $\mathrm{HCl}-$ DMSO solutions, let us consider the properties exhibited by the electrolyte solution employed. As is known, the solvent dissociates as follows, 23.93

$$
2\left(\mathrm{CH}_{3}\right)_{2} \mathrm{SO} \rightleftarrows\left[\left(\mathrm{CH}_{3}\right)_{2} \mathrm{SO}\right] \mathrm{H}^{+}+\left(\mathrm{CH}_{3} \mathrm{SOCH}_{2}\right)^{-} \text {. }
$$

The ionization of solvent formally resembles that of water, although the corresponding equilibrium constant is at least four orders of magnitude smaller than that of water $\left(K_{\mathrm{DMSO}}=5 \times 10^{-18}\right.$ mole $/ 1$. at $\left.25^{\circ} \mathrm{C}\right) .^{28}$ Lower values of $K_{\mathrm{DMso}}$ have also been reported. ${ }^{33}$

Hydrogen chloride behaves in DMSO as a strong electrolyte in which ionic association occurs to a certain extent at high concentrations. ${ }^{34}$ The equilibrium constant for ion-pair formation is $K_{\mathrm{a}}=115.71 . / \mathrm{mole}$ at $25^{\circ} \mathrm{C}$. Therefore in acid mebia the amount of $\left(\mathrm{CH}_{3} \mathrm{SOCH}_{2}\right)^{-}$ion must be very low.

\section{Probable anodic mechanisms for iron dissolution}

Mechanism (i). After the previous considerations, a probable mechanism for the anodic reaction can be written

$$
\begin{gathered}
\mathrm{Fe}+\left(\mathrm{CH}_{3} \mathrm{SOCH}_{2}\right)^{-}=\mathrm{Fe}\left(\mathrm{CH}_{3} \mathrm{SOCH}_{2}\right)_{\mathrm{ad}}+\mathrm{e}, \\
\mathrm{Fe}\left(\mathrm{CH}_{3} \mathrm{SOCH}_{2}\right)_{\mathrm{ad}} \stackrel{\mathrm{rds}}{\longrightarrow} \mathrm{Fe}\left(\mathrm{CH}_{3} \mathrm{SOCH}_{2}\right)^{+}+\mathrm{e}, \\
\mathrm{Fe}\left(\mathrm{CH}_{3} \mathrm{SOCH}_{2}\right)^{+}=\mathrm{Fe}^{2+}+\left(\mathrm{CH}_{3} \mathrm{SOCH}_{2}\right)^{-} .
\end{gathered}
$$


Reaction (i.1) may also occur as with the participation of the solvent molecule,

$$
\begin{aligned}
& \mathrm{Fe}+\left(\mathrm{CH}_{3}\right)_{2} \mathrm{SO}=\mathrm{Fe}\left(\mathrm{CH}_{3} \mathrm{SOCH}_{3}\right)_{\mathrm{ad}}, \\
& \mathrm{Fe}\left(\mathrm{CH}_{3} \mathrm{SOCH}_{3}\right)_{\mathrm{ad}}=\mathrm{Fe}\left(\mathrm{CH}_{3} \mathrm{SOCH}_{2}\right)_{\mathrm{ad}}+\mathrm{H}_{\mathrm{solv}}^{+}+\mathrm{e}, \\
& \mathrm{Fe}\left(\mathrm{CH}_{3} \mathrm{SOCH}_{2}\right)_{\mathrm{ad}} \stackrel{\mathrm{rds}}{\longrightarrow} \mathrm{Fe}\left(\mathrm{CH}_{3} \mathrm{SOCH}_{2}\right)^{+}+\mathrm{e}, \\
& \mathrm{Fe}\left(\mathrm{CH}_{3} \mathrm{SOCH}_{2}\right)^{+}=\mathrm{Fe}^{2+}+\left(\mathrm{CH}_{3} \mathrm{SOCH}_{2}\right)^{-}, \\
&\left(\mathrm{CH}_{2} \mathrm{SOCH}_{2}\right)^{-}+\mathrm{H}_{\mathrm{solv}}^{+}=\left(\mathrm{CH}_{3}\right)_{2} \mathrm{SO} .
\end{aligned}
$$

Both reaction schemes are formally analogous as there is always an electron-transfer step which is a fast process preceding the rate-determining step, which also involves a second electron transfer. The second presentation however appears more realistic as it pictures the adsorption of the solvent molecule at the metal/solution interface, which probably occurs to a large extent, and avoids the straightforward participation in the initial reaction of an ion existing at very low concentration in acid solutions (as in mechanism (i)). The theoretical kinetic parameters derived for both anodic mechanisms are alike and agree with those experimentally obtained.

Reaction (ii.1) corresponds to the adsorption equilibrium of the solvent on the iron electrode. Taking into account the structural configuration of the solvent molecule ${ }^{25}$ it may be postulated that its degree of coverage, $X_{\mathrm{s}}$, at anodic overvoltage is large $\left(X_{\mathrm{s}} \rightarrow 1\right)$. The electron transfer according to step (ii.2) yields a surface complex of ionic structure,

$$
\mathrm{Fe}\left(\mathrm{CH}_{3} \mathrm{SOCH}_{3}\right)_{\mathrm{ad}} \rightarrow \mathrm{Fe}^{+}\left(\mathrm{CH}_{2} \mathrm{SOCH}_{3}\right)_{\mathrm{ad}}^{-}+\mathrm{H}_{\text {solv }}^{+}+\mathrm{e} \text {, }
$$

where the charge distribution allows a stabilization of the surface compound. Its ionic structure involves an electronic density decrease on the sulphur atom, as the iron atom is bound to the rest through the oxygen atom, causing a stabilization of the surface intermediate. This is analogous to the stability of ferrous and ferric ionic complexes in DMSO solutions where the solvent molecule is likewise bound to the iron through the oxygen atom. ${ }^{21.22}$ Furthermore, the postulated structure for the surface intermediate means a stabilization of the $\mathrm{S}-\mathrm{C}$ bond by a delocalization of the free electrons on the carbon atom. As the metal is mainly covered by solvent molecules the degree of surface coverage by the intermediate must be low $\left(X_{1} \rightarrow 0\right)$.

The intermediate participates directly in the rate-determining step and the assumption for its low surface concentration is justified in terms of the low electrochemical double layer capacitance at any anodic overvoltage, as deduced from the non-steady measurements. The final reaction is a fast reaction corresponding to the solvolysis equilibrium of ferrous ion in $\mathrm{HCl}-\mathrm{DMSO}$ solutions.

Applying the quasi-steady state method to derive the theoretical kinetic parameters involved in the preceding mechanisms, we get

$$
\left.\begin{array}{rl}
\frac{\mathrm{d} X_{1}}{\mathrm{~d} t}=0=v_{1}- & v_{-1}-v_{2}=\left(1-X_{1}\right) k_{1} \exp (\beta V F / R T) \\
-k_{-1} X_{1} c_{\mathrm{H}} \exp [-(1-\beta) V F / R T]-k_{2} X_{1} \exp (\beta V F / R T)
\end{array}\right\},
$$

where $v_{1}$ is the reaction rate for step $\mathrm{i}$ in the anodic $(+\mathrm{i})$ and the cathodic $(-\mathrm{i}) \mathrm{di}-$ rections respectively. From (18),

$$
X_{1}=\frac{k_{1} \exp (\beta V F / R T)}{k_{1} \exp (\beta V F / R T)-k_{-1} c_{\mathrm{H}} \exp [-(1-\beta) V F / R T]-k_{2} \exp (\beta V F / R T)},
$$


which, taking into account $X_{1} \rightarrow 0$,

$$
k_{1} \exp (\beta V F / R T) \ll k_{-1} c_{\mathrm{H}} \exp [-(1-\beta) V F / R T],
$$

and simplifying the expression for $X_{\mathrm{i}}$, gives

Therefore, the reaction rate is

$$
X_{\mathrm{i}}=\frac{k_{1}}{k_{-1} c_{\mathrm{H}}} \exp (V F / R T) .
$$

$$
v_{2}=k_{2} K c_{\mathrm{H}^{-1}} \exp (V F / R T) \exp (\beta V F / R T) .
$$

According to (22) the theoretical Tafel slope is

$$
\left(\frac{\partial V}{\partial \ln i_{\mathrm{a}}}\right)_{c_{\mathrm{H}}}=\frac{2}{3} \frac{R T}{F}
$$

and the reaction order, at constant anodic potential, with respect to the concentration of hydrogen ion is

$$
\left(\frac{\partial \ln i_{\mathrm{a}}}{\partial \ln c_{\mathrm{H}}}\right)_{\mathrm{v}}=-1
$$

However, as noticed earlier for the cathodic evolution of hydrogen, $V$ is given by

and

$$
V=\phi_{\mathrm{corr}}^{\mathrm{m}}+\eta-\psi_{1}
$$

$$
\phi_{\mathrm{corx}}^{\mathrm{m}}=\phi_{\mathrm{corr}}^{0, \mathrm{~m}}+\frac{R T}{F} \ln c_{\mathrm{H}},
$$

and any variation of $\psi_{1}$ with concentration of hydrogen ion has been neglected since the experiments were carried on in the presence of a large excess of supporting electrolyte. The same criterion has been applied as far as the activity coefficients are concerned. On these grounds, the expression for $i_{\mathrm{a}}$ can be written

$$
\ln i_{\mathrm{a}}=K^{\prime}-\ln c_{\mathrm{H}}+\frac{3}{2} \ln c_{\mathrm{H}}+\frac{3}{2} \frac{F}{R T} \eta \text {. }
$$

The constant $K^{\prime}$ embodies all terms independent of $c_{H}$ and $\eta$. The reaction order derived from (27), at constant $\eta$ and $\psi_{1}$, is

$$
\left(\frac{\partial \ln i_{\mathrm{a}}}{\partial \ln c_{\mathrm{B}}}\right)_{\eta, \psi_{\mathrm{l}}}=-1+\frac{3}{2}=\frac{1}{2}
$$

which corresponds to that actually measured.

From the postulated mechanism, the equation giving the dependence of the corrosion potential on acid concentration is obtained immediately. Thus, taking the following set of parameters, $n_{\mathrm{H}}=-1, m_{\mathrm{H}}=1, \alpha_{\mathrm{a}, \mathrm{Fe}}=\frac{3}{2}$ and $\alpha_{\mathrm{c}, \mathrm{H}}=\frac{1}{2}$, becomes

and

$$
E_{\mathrm{corr}}=E_{\mathrm{k}}+\frac{R T}{F} \ln c_{\mathrm{H}}
$$

$$
\left(\frac{\partial E_{\text {corr }}}{\partial \ln c_{\mathrm{H}}}\right)=\frac{R T}{F}
$$


Finally, applying the same set of parameters to (15) we obtain

$$
\left(\frac{\partial \ln i_{\text {corr }}}{\partial \ln c_{\text {H }}}\right)=\frac{1}{2}
$$

\section{Probable cathodic mechanism for iron deposition}

The reverse mechanisms involving the same rate-determining step should be valid for the electrodeposition of iron. Thus, starting from the set of parameters mentioned above for the anodic reactions, those of the cathodic reaction should take the complementary values $\alpha_{\mathrm{e}, \mathrm{Fe}}=\frac{1}{2}$ and $n_{\mathrm{Fe}}=1$. Furthermore, the former is already derived from the experimental results as the steady Tafel slope is equal to $2 R T / F$, and the rate of the cathodic process increases with the ferrous ion concentration.

Let us then write the probable mechanism for the electrodeposition of iron as

$$
\begin{aligned}
& \mathrm{Fe}_{\mathrm{Bolv}}^{2++}+\left(\mathrm{CH}_{3}\right)_{2} \mathrm{SO}=\mathrm{Fe}\left(\mathrm{CH}_{3} \mathrm{SOCH}_{2}\right)^{+}+\mathrm{H}_{\mathrm{Bolv}}^{+}, \\
& \mathrm{Fe}\left(\mathrm{CH}_{3} \mathrm{SOCH}_{2}\right)^{+}+\mathrm{e} \stackrel{\mathrm{rds}}{\longrightarrow} \mathrm{Fe}\left(\mathrm{CH}_{3} \mathrm{SOCH}_{2}\right)_{\mathrm{ad}}, \\
& \mathrm{Fe}\left(\mathrm{CH}_{3} \mathrm{SOCH}_{2}\right)_{\mathrm{ad}}+\mathrm{H}_{\mathrm{solv}}^{+}+\mathrm{e}=\mathrm{Fe}\left(\mathrm{CH}_{3} \mathrm{SOCH}_{3}\right)_{\mathrm{ad}}, \\
& \mathrm{Fe}\left(\mathrm{CH}_{3} \mathrm{SOCH}_{3}\right)_{\mathrm{ad}}=\mathrm{Fe}+\left(\mathrm{CH}_{3}\right)_{2} \mathrm{SO} .
\end{aligned}
$$

The rate equation for the rate-determining step (iii.2) is

$$
v_{\text {i11.2 }}=k_{\text {i11.2. }} c_{\mathrm{Fe}} c_{\mathrm{H}} \exp [-(1-\beta) V F / R T] \text {, }
$$

and on the assumption that $\beta=\frac{1}{2}$, the theoretical Tafel slope for iron electrodeposition is

$$
\left(\frac{\partial V}{\partial \ln i_{\mathrm{c} . \mathrm{Fe}}}\right)_{\epsilon_{\mathrm{H}, c_{\mathrm{re}}}}=-\frac{2 R T}{F}
$$

Therefore, the intersection of the Tafel lines for the iron electrode reactions define both the reversible potential of the iron electrode and the corresponding exchange $\mathrm{cd}$, which is of the order of $10^{-8} \mathrm{~A} / \mathrm{cm}^{2}$.

Acknowledgements-D. P. acknowledges the fellowship granted by the Consejo Nacional de Investigaciones Cientificas y Técnicas of Argentina. This work was in part done with funds provided by the C.N.I.C.T.

\section{REFERENCES}

1. K. E. HeUsLer and K. F. BONHOEFFER, Z. Elektrochem. 61, 122 (1957).

2. K. E. HeusLer, $Z$. Elektrochem. 62, 582 (1958).

3. H. KAESCHE, $Z$. Elektrochem. 63, 492 (1959).

4. T. HURLEN, Acta chem. scand. 14, 1533 (1960).

5. K. A. Christiansen, H. Heg, K. Michelsen, K. Bech, S. Nielsen and H. Nord, Acta chem. scand. 15, 300 (1961).

6. J. O'M. Bockris, D. Draztc and A. R. Despic, Electrochim. Acta 4, 325 (1961).

7. J. O'M. Bockris and D. DrAzIC, Electrochim. Acta 7, 293 (1962).

8. T. HuRLEN, Electrochim. Acta 7, 563 (1962).

9. W. J. LORENZ, H. YAMAOKA and H. FISCHER, Ber. Bunsenges. phys. Chem. 67, 932 (1963).

10. E. J. KeLLY, J. electrochem. Soc. 112, 124 (1965).

11. J. J. Podestí and A. J. Arvia, Electrochim. Acta 10, 171 (1965).

12. G. EICHKORN and W. J. LORENZ, Naturwissenschaften 52, 618 (1965).

13. W. J. LoRenz, Corros. Sci. 5, 121 (1965).

14. W. J. LoRenz and G. EICHKoRn, Ber. Bunsenges. phys. Chem. 70, 99 (1966).

15. J. J. Podestá and A. J. ArviA, An. Asoc. quim. argent. 55, 3 (1967).

16. S. M. Florianovich, L. A. Sokolova and Y. M. KolotyrkIN, Elektrokhimiya 3, 1027 (1967). 
17. G. Eickhorn, W. J. Lorenz, L. Albert and H. Fischer, Electrochim. Acta 13, 183 (1968).

18. P. G. Sears, G. R. Lester and R. L. Dawson, J. phys. Chem. 60, 1433 (1956).

19. J. A. Bolzan, M. C. Giordano and A. J. Arvi, An. Asoc. quim. argent. 54, 171 (1966).

20. J. A. Olane and A. J. ArviA, Electrochim. Acta 14, 785 (1969).

21. J. Selbin, W. E. Bull and L. H. Holmes, J. inarg, nucl. Chem. 16, 219 (1961).

22. F. A. Cotton and R. Francis, J. Am. chem. Soc. 82, 2986 (1960).

23. M. Monewa, M. Suwalsky and O. Weinerts, Rev. Real. Acad. Cienc. Ex. Fis. Nat. Madrid 60, 649 (1966).

24. W. F. CURrIER and J. H. Weber, Inorg. Chem. 6, 1539 (1967).

25. D. Posadas, J. J. Podestí and A. J. Arvia, Electrochim. Acta, 15, 1225 (1970).

26. J. R. GALVELE, private communication.

27. F. J. WAllace and J. J. MAHON, Nature 201, 817 (1964).

28. I. M. KOLTHOPf and T. B. REDDY, Inorg. Chem. 1, 189 (1962).

29. J. A. Olabe, M. C. Glordano and A. J. ARvia, Electrochim. Acta 12, 907 (1967).

30. M. Griffin and M. G. Melion, Analyt. Chem. 19, 1017 (1947).

31. B. E. ConwaY, Theory and Principles of Electrode Processes. Ronald, New York (1965).

32. J. N. BUTLER, J. electroanal. Chem. Interf. Electrochem. 14, 89 (1967).

33. A. Collumeau, Bull. Soc. chim. Fr. 4317 (1968).

34. J. A. Bolzan and A. J. Arvia, Electrochim. Acta 15, 39, 827 (1970).

35. O. Bastlansen and H. Viervoll, Acta chem. scand. 2, 702 (1948). 